\begin{tabular}{|c|c|c|c|c|c|c|}
\hline \multirow{4}{*}{ Impact Factor: } & ISRA (India) & $=3.117$ & SIS (USA) & $=0.912$ & ICV (Poland) & $=6.630$ \\
\hline & ISI (Dubai, UAE & $=0.829$ & РИНЦ (Russia) & $=0.156$ & PIF (India) & $=1.940$ \\
\hline & GIF (Australia) & $=0.564$ & ESJI (KZ) & $=8.716$ & IBI (India) & $=4.260$ \\
\hline & JIF & $=1.500$ & SJIF (Morocco) & $=5.667$ & OAJI (USA) & $=0.350$ \\
\hline
\end{tabular}

\begin{tabular}{|c|c|}
\hline $\begin{array}{l}\text { SOI: } \frac{1.1 / \mathrm{TA}}{\mathrm{Sc}} \\
\text { International Sc} \\
\text { Theoretical } \mathbf{\&}\end{array}$ & $\begin{array}{l}\text { AS } \text { DOI: } 10.15863 / T A S \\
\text { cientific Journal } \\
\text { Applied Science }\end{array}$ \\
\hline p-ISSN: 2308-4944 (print) & e-ISSN: 2409-0085 (online) \\
\hline Year: 2019 Issue: 05 & Volume: 73 \\
\hline Published: 30.05 .2019 & http://T-Science.org \\
\hline
\end{tabular}

SECTION 31. Economic research, finance, innovation, risk management.
QR - Issue

QR - Article

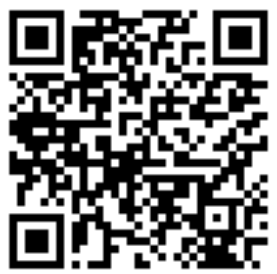

Munavvar Ibragimovna Karimjonova senior teacher of "Economic sciences" department at the Customs Institute of the State Customs Committee, Republic of Uzbekistan

\title{
CRITERIAS FOR THE REGULATION OF THE ORGANIZATION OF THE ACCOUNTING PROCEDURE OF WAGES AND INTERNAL CONTROL OF WORKERS OF CUSTOMS AUTHORITIES OF THE REPUBLIC OF UZBEKISTAN
}

\footnotetext{
Abstract: This article describes the features, goals and objectives of the payment for the work of the customs authority. Also, theoretical and practical suggestions and recommendations have been made to improve existing normative legal acts on payment of labor. The Customs Institute was selected as the object of the study.

Key words: budget organization, money supply, wages, sources of financing, pedagogical activity, scientific potential.

Language: English

Citation: Karimjonova, M. I. (2019). Criteria's for the regulation of the organization of the accounting procedure of wages and internal control of workers of customs authorities of the republic of Uzbekistan. ISJ Theoretical \& Applied Science, 05 (73), 419-425.

Soi: http://s-o-i.org/1.1/TAS-05-73-62 Doi: crossef https://dx.doi.org/10.15863/TAS.2019.05.73.62
}

\section{Introduction}

Today, thanks to the gradual reforms in the budget system and the system of customs authorities in the Republic of Uzbekistan, in the context of a strong competitive market economy, it is important to improve the order of targeted and effective use of state budget funds in the country, as well as the order of payment of salaries, pensions and other payments. Because it is one of the most pressing issues to economize on budget expenditures by the most important cost estimates. In this regard, one of the most important priorities is to reflect them accurately and accurately in accounts and reports. The President of the Republic of Uzbekistan issued the Decree "On the State Program on Implementation of the Strategy of Action on the Development of the Republic of Uzbekistan in Five Priority Areas for the Development of the Republic of Uzbekistan in 20172021" at the "Year of Active Investments and Social Development" dated January 17, 2019. It set priorities for the further development of the system of budgetary resources efficient use and inter-budgetary relations, based on the priorities of economic development and active investment attraction [1]. Including:

$>$ identifying the stages and directions for the introduction of targeted budgeting system in
Uzbekistan jointly with international financial institutions, deeply studying the world experience in this field;

$>$ Development of qualitative and quantitative indicators and evaluation indicators on budget-funded programs and projects;

$>$ creation of standards for audit of effectiveness of budgetary funds;

$>$ Improving the rules and procedures for allocating high budget targeted budgetary funds (transfers) by the end of 2020, ie setting up an order that sets out the single approach;

$>$ Unification of the norms of taxes left to the local budget from 2021 and the introduction of a threeyear review practice;

$>$ to create a normative legal basis for the implementation of tasks such as gradual transferring the localization expenditure budget from the budget to the lower budget.

The point is: "We all know that reform means renovation, change. In order for the reforms to succeed, first of all, our leaders and our people need to change. When a person changes, society changes. " It is necessary to further improve the system for the efficient use of budgetary funds. Any program or project whose budget has been funded should include 


\begin{tabular}{|c|c|c|c|c|c|c|}
\hline \multirow{4}{*}{ Impact Factor: } & ISRA (India) & $=3.117$ & SIS (USA) & $=0.912$ & ICV (Poland) & $=6.630$ \\
\hline & ISI (Dubai, UAE & $=0.829$ & РИНЦ (Russia & $=0.156$ & PIF (India) & $=1.940$ \\
\hline & GIF (Australia) & $=0.564$ & ESJI (KZ) & $=8.716$ & IBI (India) & $=4.260$ \\
\hline & JIF & $=1.500$ & SJIF (Morocce & $=5.667$ & OAJI (USA) & $=0.350$ \\
\hline
\end{tabular}

quality and quantity indicators and have resultoriented indicators. "[2]

\section{Literature review}

Issues of legal regulation of wages, including wages of public sector workers, were widely covered by CIS scientists such as: N. N. Abakumova, R. Ya. Podovalova [10], E. B. Pasherstnik, M. S. Meyksin, N V. Pasherstnik [11], A. D. Zaikin, K. S. Remizov [12], M. V. Karlova [13], V. Glazyrin [14], and others.

\section{Analysis and results}

In the consistent policy pursued by the President of the Republic, the government of our country, a special attention is paid to the richness and prosperity of the people, the support of entrepreneurs, the creation of a solid foundation for economic development and development.

Labor relations in our country are based on the norms of the Constitution of the Republic of Uzbekistan and the Labor Code [3].

One of the main factors in enriching the people and providing them with decent living conditions is the challenge of rewarding, encouraging. Unfortunately, there have been many acute problems and shortcomings over the years, and it is not possible to solve them shortly. Labor relations in the competitive economy are becoming more complicated than ever before. Solving the problem of real employment, limited workplaces, relative surplus in the workforce, degrees of employment in the globalized economy, social benefits, labor protection, incentives, productivity and productivity are among the most important issues we face today.

So, what changes and tendencies are observed in today's globalized, strong competitive economy. The first and most important factor of the problem is the proper determination of its minimum standards for living.

According to the EU statistics agency, the richest country in the European Union - the minimum monthly wage in Luxembourg is nine times higher than in the poorest country in the European Union Bulgaria. It is said that the minimum monthly wage in Luxembourg is currently Euro 1999 and 235 euros in Bulgaria. In addition to Luxembourg, Ireland is 1,563 Euros, the Netherlands 1552 Euro, Belgium 1532 Euros and Germany 1498 Euros. The lowest figures are Romania's 275 Euros, Latvia 380 Euros, Lithuania 380 Euros and 407 Euros in the Czech Republic.

In addition, six of the $28 \mathrm{EU}$ countries have no "minimum wage" concept. These are Denmark, Sweden, Italy, Cyprus, Slovakia and Croatia. In the ranking of average wages in different countries, we can see the following countries. This rating includes 157 countries. The first place is in Switzerland. The average wage in this country is $\$ 3,355$. In Kuwait, which is on the second place, this is $\$ 3,111$. The average salary in the United States is \$3,202.

Among CIS countries, the highest figure is in Russia - \$ 615. Kazakhstan is ranked 480, Belarus 375 and Turkmenistan at $\$ 320$. It is noted that in Tajikistan, this figure is about $\$ 110$. The lowest point is in Zimbabwe - an average of $\$ 21$ a month. Uzbekistan ranks 118th on this rating. The average salary in Uzbekistan is \$ 235.

The Strategy for Action in the five priority areas of Uzbekistan's development in 2017-2021 and the State Program "Year of Support for Innovative Business, Innovation Ideas and Technology" will focus on the development of social sphere, social protection of the population, taking into account trends of international economic relations and investment attractiveness of the country. and the further improvement of the labor payment system. The program also notes that the real incomes of the population in 2018 increased by $12 \%$ compared with 2017. Currently, the President of the Republic of Uzbekistan, issued on May 21, 2012, has adopted the Law of the Republic of Uzbekistan "On the improvement of the procedure for payment of wages, pensions and other payments", PF-5723, "On improvement of the procedure for payment of salaries, pensions and other payments" Decree "was adopted. Accordingly, the differences between the minimum wage and the minimum monthly wage and the principles of their implementation were determined. In accordance with the decree, from September 1, 2019 , the following amounts have been set instead of the minimum wage: [4]

- minimum amount of remuneration - 577170 soums;

- basic calculation - 202730 soums;

- The basic amount of pension calculation - 202 730 soums. 


\begin{tabular}{llllll} 
& ISRA (India) $=\mathbf{3 . 1 1 7}$ & SIS (USA) & $=\mathbf{0 . 9 1 2}$ & ICV (Poland) & $=\mathbf{6 . 6 3 0}$ \\
Impact Factor: & ISI (Dubai, UAE) $=\mathbf{0 . 8 2 9}$ & PUHL (Russia) $=\mathbf{0 . 1 5 6}$ & PIF (India) & $=\mathbf{1 . 9 4 0}$ \\
& GIF (Australia) $=\mathbf{0 . 5 6 4}$ & ESJI (KZ) & $=\mathbf{8 . 7 1 6}$ & IBI (India) & $=\mathbf{4 . 2 6 0}$ \\
& JIF & $\mathbf{1 . 5 0 0}$ & SJIF (Morocco) $=\mathbf{5 . 6 6 7}$ & OAJI (USA) & $\mathbf{0 . 3 5 0}$ \\
\hline
\end{tabular}

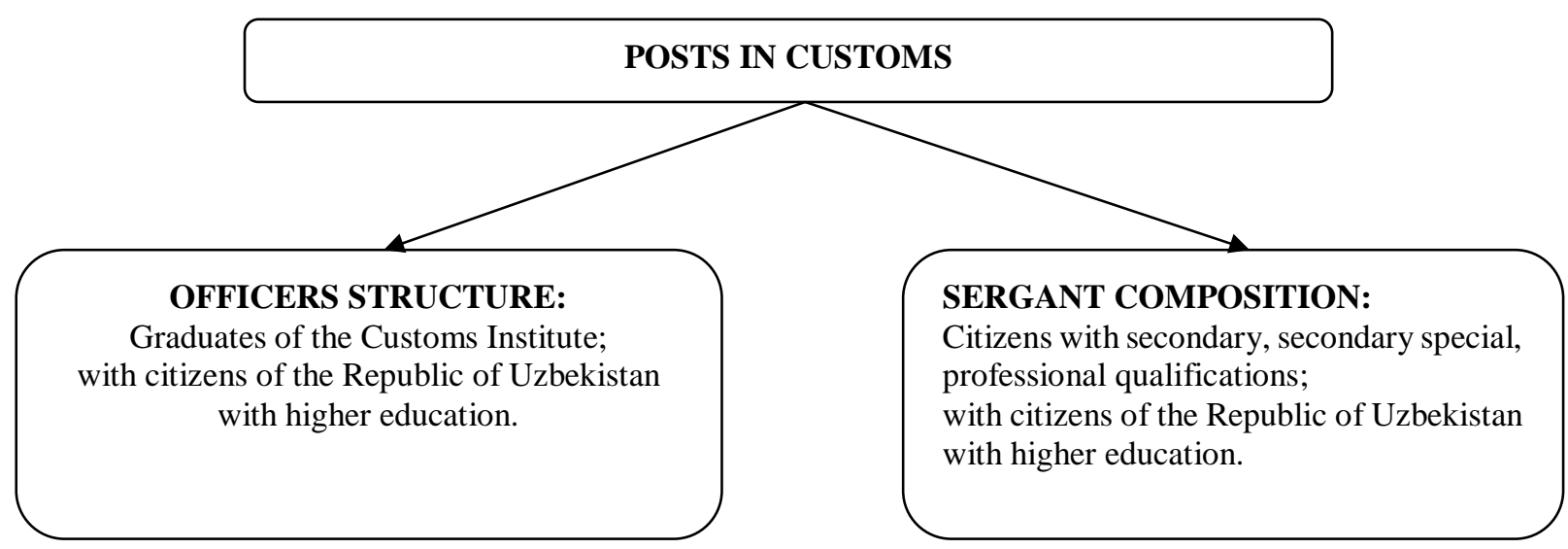

Fig.1. Structure of positions in customs authorities

Based on the above, it is safe to say that the labor relations in the Republic of Uzbekistan are successfully regulated on the basis of the principles of justice established by law.

As a result of step-by-step reforms in our country, it also required a radical improvement of the activities of the State Customs Service and identified a number of urgent tasks [5]. Including:

protection of the rights, freedoms and legally protected interests of individuals and legal entities;

within its competence to protect the economic interests of the Republic of Uzbekistan and ensure its economic security;

customs clearance and registration;

collection of customs payments;

including prevention, detection and suppression of smuggling;

Monitoring of foreign trade operations, analysis of execution of export-import contracts, as well as observance of currency legislation on foreign trade operations in respect of customs authorities; maintaining customs statistics on foreign trade and commodity nomenclature of foreign economic activity;

increasing the legal culture of citizens in the customs area;

systematic monitoring of the effectiveness of the risk management system;

Application of modern information and communication technologies and control over the activities of customs authorities;

development of priority directions of customs development and improvement;

Effective implementation of these tasks requires the training of highly skilled, highly qualified professionals in customs. This requires the proper organization of the procedure for keeping and paying employees of the customs service.

The Customs authorities are the lawenforcement organs in which the staff of officers and sergeants, who have special ranks, and the staff of the service personnel, carry out the activity. Positions on customs authorities are summarized as follows [6]. See the picture upper. (Fig.1))

Table- 1. Special ranks of employees of customs authority

\begin{tabular}{|l|l|l|}
\hline$\#$ & Structure of special titles & Titles \\
\hline $\mathbf{1 .}$ & Sergeants Structure: & $\begin{array}{l}\text { - Small sergeant for customs clearance; } \\
- \text { Customs sergeant; } \\
\text { - Large sergeant for customs service. }\end{array}$ \\
\hline $\mathbf{2 .}$ & Officers Structure: & \\
\hline & small officers' structure & $\begin{array}{l}\text { - lieutenant of customs service; } \\
- \text { Senior Lieutenant for Customs Service; } \\
\text { - Captain of customs service. }\end{array}$ \\
\hline & Major officers & $\begin{array}{l}\text { - Customs Service Major; } \\
\text { - lieutenant colonel of customs service; } \\
\text { Colonel of customs service. }\end{array}$ \\
\hline 3. & General Structure: & $\begin{array}{l}\text { Major-Major of Customs Service; } \\
\text { Lieutenant General of Customs Service; } \\
\text { General Colonel of Customs Service. }\end{array}$ \\
\hline
\end{tabular}




\begin{tabular}{|c|c|c|c|c|c|c|}
\hline \multirow{4}{*}{ Impact Factor: } & ISRA (India) & $=3.117$ & SIS (USA) & $=0.912$ & ICV (Poland) & $=6.630$ \\
\hline & ISI (Dubai, UAE & $=0.829$ & РИНЦ (Russia & $=0.156$ & PIF (India) & $=1.940$ \\
\hline & GIF (Australia) & $=0.564$ & ESJI (KZ) & $=8.716$ & IBI (India) & $=4.260$ \\
\hline & JIF & $=1.500$ & SJIF (Morocce & $=5.667$ & OAJI (USA) & $=0.350$ \\
\hline
\end{tabular}

The customs authority shall exercise the rights and freedoms set forth in the Constitution of the Republic of Uzbekistan, the legislation and the State Customs Committee's internal normative acts. The Customs authorities shall act as the representative of the state body and shall be under the protection of the State of the Republic of Uzbekistan in carrying out their official duties in accordance with their respective roles and functions.

In the system of customs bodies, there are 4248 personnel consisting of officers and sergeants, having a special title. The main tasks of the Customs officers' employees, depending on their particular working conditions and specific features, are recorded and paid for. Categorization of customs posts on the basis of characteristic and scope of their service plays a crucial role in their payment. For each category, the maximum allowance is set according to the specific working conditions [7]. The following table shows how:

Table-2. Types of types and salaries of customs officers, taking into account their specific working conditions and working capacity

\begin{tabular}{|l|l|l|l|l|l|l|}
\hline T\p & Name of categories & \multicolumn{3}{l}{ Border Customs Offices } & $\begin{array}{l}\text { Customs posts of foreign } \\
\text { economic activity }\end{array}$ & $\begin{array}{l}\text { Amount } \\
\text { premiums }\end{array}$ \\
\cline { 3 - 7 } & & $\begin{array}{l}\text { the } \\
\text { number }\end{array}$ & state unity & $\begin{array}{l}\text { of } \\
\text { the } \\
\text { number }\end{array}$ & state unity & In \% \\
\hline 1. & Customs offices except sate & 17 & 1316 & 6 & 284 & 40 \\
\hline 2. & First category customs posts & 17 & 490 & 21 & 349 & 35 \\
\hline 3. & Second class customs posts & 23 & 390 & 26 & 242 & 30 \\
\hline 4. & Kinologists & & & & & 20 \\
\hline & Total & 57 & 2196 & 53 & 875 & \\
\hline & Overall & 110 posts & 3071 state unity & \\
\hline
\end{tabular}

The purpose of the registration and payment of the employees of the customs service is to improve the relationships between employees, based on the specificities of the customs system, to justify the labor norms, ensure the effective use of the expenditure estimates, and build trustworthy financial and economic activities.

Customs authorities are a non-commercial organization maintained at the expense of the State budget funds, ie the budget organization is regulated on the basis of the norms of the Budget Code of the Republic of Uzbekistan and the payment is made at the expense of budgetary funds. It should be noted that customs officials carry out their fiscal responsibilities in replenishment of state budget revenues while carrying out their activity. By the end of 2018 employees of the Customs Service will receive 11.5 billion soums. The customs payments were collected and timely transfer to the state budget was ensured 


\begin{tabular}{|c|c|c|c|c|c|c|}
\hline \multirow{4}{*}{ Impact Factor: } & ISRA (India) & $=3.117$ & SIS (USA) & $=0.912$ & ICV (Poland) & $=6.630$ \\
\hline & ISI (Dubai, UAE & $=0.829$ & РИНЦ (Russia & $=0.156$ & PIF (India) & $=1.940$ \\
\hline & GIF (Australia) & $=0.564$ & ESJI (KZ) & $=8.716$ & IBI (India) & $=4.260$ \\
\hline & JIF & $=1.500$ & SJIF (Morocco & $=5.667$ & OAJI (USA) & $=0.350$ \\
\hline
\end{tabular}

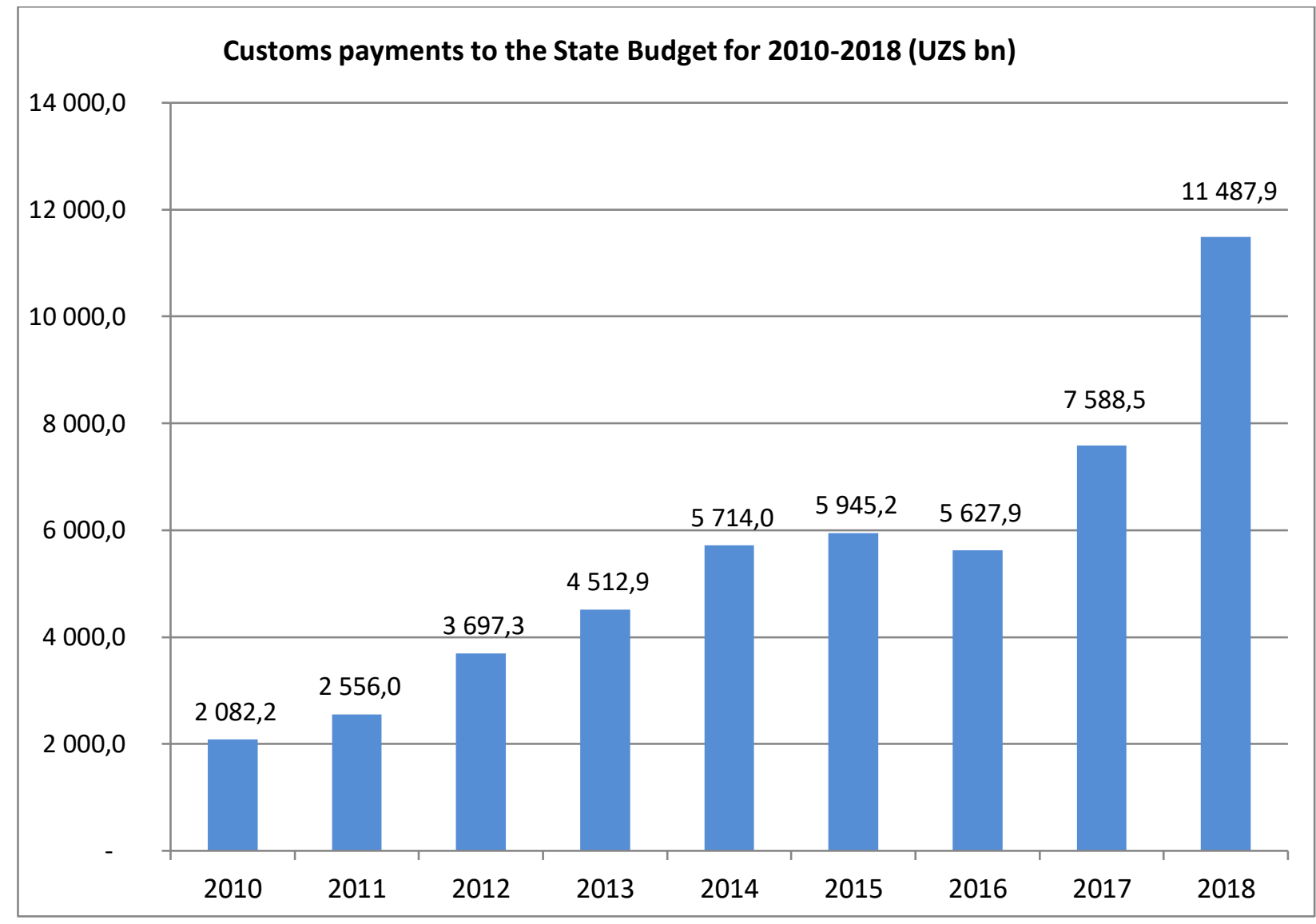

Fig.2. Customs payments to the State Budget

At present, the Customs authorities carry out annually the prospective plans for these customs payments.

Successful implementation of the tasks on liberalizing the foreign economic activity, enhancing investment attractiveness and strengthening the country's export potential are largely dependent on the effective organization of the customs authorities, in particular, the insufficient use of opportunities for material incentives for customs officers to prevent corruption and overall system effectiveness indicates that the In order to avoid these problems, due to the conscientious performance of customs duties, high professional level and moral and ethical character, the Government of the Republic of Uzbekistan issued a number of Decrees and Resolutions [8].

Including:

According to the Decree of the President of the Republic of Uzbekistan from April 12, 2018 "About measures on cardinal improvement of activity of bodies of the State Customs Service of the Republic of Uzbekistan" and the Decree of the President of the Republic of Uzbekistan from April 12, 2018 "About organization of activity of bodies of the State Customs Service of the Republic of Uzbekistan" 3665 RESOLUTION OF THE PRESIDENT OF THE REPUBLIC OF UZBEKISTAN from November 2,
2018 on measures to radically improve the system of training of customs agents of the Republic of Uzbekistan On the introduction of amendments and supplements to certain resolutions of the Government of the Republic of Uzbekistan (the Resolution of the President of the Republic of Uzbekistan No. PP-3995) "On additional measures to improve the customs administration and increase the effectiveness of the activities of the State Customs Service of the Republic of Uzbekistan" additional changes and additions were introduced in the system of labor payment based on the requirements of the main tasks and directions of the service.

The adoption of these decrees and resolutions is fundamentally reformed to materialize the system of labor compensation for the workers of the customs authority, as starting from November 2018, according to approved rates of remuneration of labor tariffs for employees of the State Customs Service of the Republic of Uzbekistan the coefficients of the coefficients were used in 1.7 times. The staff of the customs authority has been financed due to a $50 \%$ increase in salaries for special working conditions and at least $70 \%$ for professorial teachers of the Customs Institute.

The analysis shows that in the course of the past 2018, the payment for the work of the customs 


\begin{tabular}{|c|c|c|c|c|c|c|}
\hline \multirow{4}{*}{ Impact Factor: } & ISRA (India) & $=3.117$ & SIS (USA) & $=0.912$ & ICV (Poland) & $=6.630$ \\
\hline & ISI (Dubai, UAI & $=0.829$ & РИНЦ (Russia & $=0.156$ & PIF (India) & $=1.940$ \\
\hline & GIF (Australia) & $=0.564$ & ESJI (KZ) & $=8.716$ & IBI (India) & $=4.260$ \\
\hline & JIF & $=1.500$ & SJIF (Morocco & $=5.667$ & OAJI (USA) & $=0.350$ \\
\hline
\end{tabular}

authority has been doubled to the current year. However, the basic amount of the salary increased to 100 percent, and the source of funding was the state budget, and the main overpayment was increased by 50-70 percent due to the funds spent from the special funds of the State Customs Committee. A source of formation of a special fund, formed at the expense of deductions of $50 \%$ of customs duties. These funds are used in accordance with expenditure estimates approved by the Ministry of Finance of the Republic of Uzbekistan.
From our point of view, it is possible to conclude that the establishment of the customs authority based on the work of the staff and the nature of their payment is a result of the efficient and efficient use of budgetary funds, taking into account the fact that accounting officers are a big responsibility, time consuming, and highly professional. for the purposes of controlling the correct use of the targeted use, labor costs and accounting in their accounting records, the State Customs it is desirable to establish the "Customs Audit Department" in the Committee. See the picture below

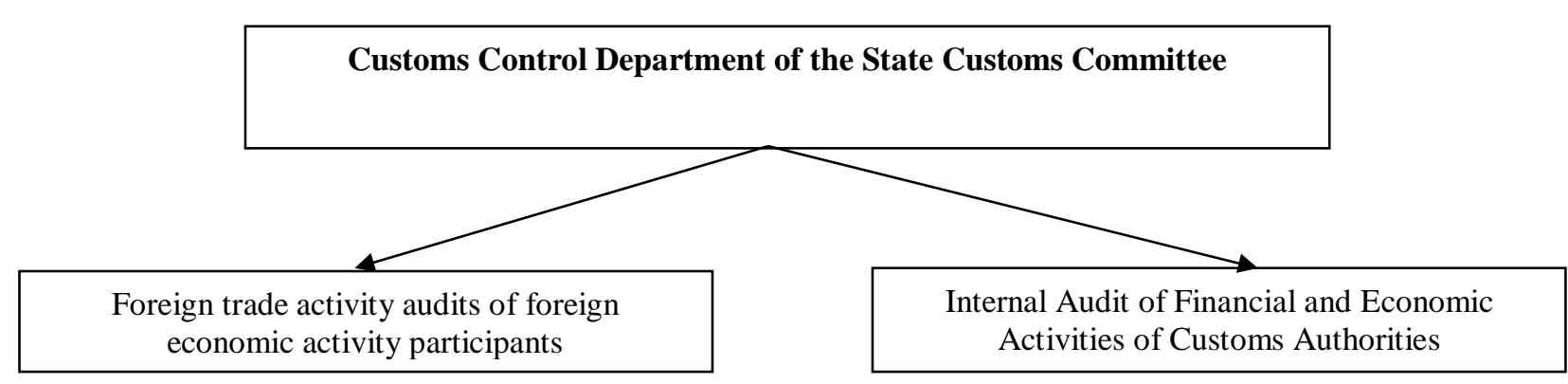

Fig.3. Structure of the Customs Control Department of the State Customs Committee

\section{Conclusions}

It should be noted that, along with the establishment of the Customs Control Office of the State Customs Committee, it is desirable to develop and implement the principles and methodology of service duties in terms of its structure.

\section{References:}

1. (2019). The Decree of the President of the Republic of Uzbekistan from January 17, 2019 of No. UP-5635 "About the state program of realization of the action strategy on five priority directions of development of the Republic of Uzbekistan for 2017-2021" in the year of active investments and social development ".

2. (2018, December 28). Application of the President of the Republic of Uzbekistan Sh.Mirziyoev to the chambers of the Oliy Majlis.

3. (1995, December 21). Labor Code of the Republic of Uzbekistan. Constitution of the Republic of Uzbekistan. Tashkent: Uzbekistan, NMIU, 2017.

4. (n.d.). To declare invalid the Presidential decree of the Republic of Uzbekistan "About enhancement of the procedure for determination of the sizes of wages, pensions and other payments".

5. (2018, October 18). Law of the Republic of Uzbekistan "On the State Customs Service" No. 502.

6. (2018). The Resolution of the President of the Republic of Uzbekistan from April 12, 2018 NP3665 "On the organization of the activity of bodies of the State Customs Service of the Republic of Uzbekistan".

7. (2018). The Presidential decree of the Republic of Uzbekistan from November 24, 2018 of N UP-5582 "About additional measures for perfection of customs administration and enhancement of efficiency of activities of the State Customs Service of the Republic of Uzbekistan". 


\begin{tabular}{|c|c|c|c|c|c|c|}
\hline \multirow{4}{*}{ Impact Factor: } & ISRA (India) & $=3.117$ & SIS (USA) & $=0.912$ & ICV (Poland) & $=6.630$ \\
\hline & ISI (Dubai, UAE & $=0.829$ & РИНЦ (Russia & $=0.156$ & PIF (India) & $=1.940$ \\
\hline & GIF (Australia) & $=0.564$ & ESJI (KZ) & $=8.716$ & IBI (India) & $=4.260$ \\
\hline & JIF & $=1.500$ & SJIF (Morocce & $=5.667$ & OAJI (USA) & $=0.350$ \\
\hline
\end{tabular}

8. (2018). Decree of the President of the Republic of Uzbekistan from April 12, 2018 "About measures on cardinal improvement of activity of bodies of the State Customs Service of the Republic of Uzbekistan" No. UP-5414.

9. (2018). The Resolution of the President of the Republic of Uzbekistan from November 2, 2018 $\mathrm{N}$ PP-3995 "About measures on cardinal improvement of the system of training of customs personnel of the Republic of Uzbekistan".

10. Abakumova, N. N., \& Podovalova, R. Y. (1999). The policy of income and wages. Moscow: InfraM.
11. Pasherstnik, E. B., Meixin, M. S., \& Pasherstnik, N. V. (2000). Wages in modern conditions. M SPb.: Gerd.

12. Zaikin, A. D., \& Remizov, K. S. (1999). Economic and legal regulation of labor and wages. Moscow: Norma.

13. Karlova, M. V. (2000). Qualification characteristics of positions and job descriptions of employees. Personnel guide, № 1 .

14. Glazyrin, V. (2002). Payment and labor regulation. Economy and law, № 8. 